\title{
Non ministrari, sed ministrare! Laudacja dla abpa Zygmunta Zimowskiego z okazji wręczenia medalu Bene Merenti Polskiego Towarzystwa Teologicznego
}

Eminencjo, Księże Kardynale! Magnificencje, Ekscelencje, szanowni Profesorowie, szanowni Członkowie Polskiego Towarzystwa Teologicznego, dostojny Laureacie, Księże Arcybiskupie Zygmuncie!

Jako laudator pragnę zwrócić uwagę na dwie przyczyny, które czynią dzisiejszą uroczystość szczególną i doniosłą. Pierwsza to ta, której rozpoznawania nauczył nas wielki mistrz teologii polskiej ks. prof. Czesław Bartnik - mój mistrz także, że na całą historię ludzką trzeba patrzeć jako na historię zbawienia, gdyż żaden odcinek ludzkiej drogi nie jest wyjęty spod troski Bożej opatrzności. Zwłaszcza teolog powołany jest do tego, by nauczyć się spoglądania na rzeczywistość oczyma Bożymi i by tego nauczać. Patrząc z tej perspektywy „teologii Ducha”, odkryjemy z pewnością, że życie Księdza Arcybiskupa wpisuje się harmonijnie w życie Kościoła i w życie samego Boga, który realizuje swój zbawczy plan dzięki posłuszeństwu umysłu i woli swoich sług.

Drugi motyw obejmuje sens dzisiejszego wyróżnienia Zasłużony dla Polskiego Towarzystwa Teologicznego. Słowo „zasłużony” mówi nam o dwóch bardzo istotnych elementach powołania chrześcijańskiego teologa: służenie Bogu i służba przepowiadania Słowa... człowiekowi. Chrystus najpiękniej określił swoją misję jako oddanie Ojcu i wyzwolenie człowieka: „Nie przyszedłem, aby mi służono, lecz aby służyć i dać swoje życie na okup za wielu" (Mk 10, 45). W tym twierdzeniu mieści się sens każdej zasługi oraz kierunek każdego zasługiwania w Królestwie Bożym. Sługa to ten, kto służy i kto jest posłuszny Panu! W tym też świetle istotne jest rozróżnienie w tytule łacińskim odznaczenia benemerenti, czyli „dobrze zasłużony”, a więc chodzi o tego, kto służył dobrze, bo służył w posłus zeńs tw i e Temu, który jest Dobry i wszystko czyni z miłości! Czy teologia nie jest w swej istocie rozeznawaniem - duchowym i racjonalnym - woli Bożej, która jest największym dobrem dla Kościoła i każdego człowieka?! Co do tego, że kapituła przyznająca odznaczenie właściwie rozpoznała, iż abp Zygmunt Zimowski dobrze sobie zasłużył na miano dobrego sługi Bożego królestwa jako teolog, nie mam żadnych wątpliwości. Hasłem posługi pasterskiej abpa Zygmunta 
Zimowskiego od czasu objęcia diecezji radomskiej są słowa Non ministrari sed ministrare - „Nie przyszedłem, aby mi służono, lecz aby służyć”. Jakże dobitnie brzmią te słowa w kontekście posłannictwa teologa, który jest pasterzem Kościoła Chrystusowego: przez te słowa arcybiskup Zimowski odsłania nam pełne znaczenie teologii, która nie tylko jest fides quaerens intellectum, ale także caritas quaerens intellectum, bo przecież każdy teolog powinien służyć swoją przemodloną i przemyślaną wiarą tym, których wiara potrzebuje wzmocnienia.

\section{Geografia zbawienia, czyli miejsca i osoby drogi powołania i posłannictwa}

W dogmatyce utarło się, by odróżniać „historię zbawienia” (Heilsgeschichte) od "geografii zbawienia" (Heilsgeographie).W tym drugim pojęciu chodzi o zwrócenie uwagi na miejsca, w których Bóg Trójjedyny udziela szczególnych swoich łask zbawienia i uświęcenia. Nierzadko są to miejsca skromne, nieprzyozdobione w monumentalne budowle, na uboczu, a może nawet $\mathrm{z}$ dala od wielkich centrów życia gospodarczego czy politycznego. Wartość tych miejsc bierze się z tego, że nawiedził je Bóg, ale... ze względu na dobro konkretnych ludzi. Dlatego ja dodam osobiście kategorię „personalizmu zbawienia" (dla porównania Heilspersonalismus), którą posługujemy się w naszej Katedrze Personalizmu na Katolickim Uniwersytecie Lubelskim. Właśnie te dwie ostatnie kategorie pozwalają nam dowartościować i ustawić: Kupienin obok Lublina, Mędrzechów obok Innsbrucka, Tarnów obok Rzymu, Stary Sącz obok Krakowa itd. Żadna z mniejszych miejscowości nie musi „czuć zażenowania”. Oto mapa geografii zbawienia, którą z łatwością rozpozna Arcybiskup, nasz Laureat.

Abp Zygmunt Zimowski urodził się 7 kwietnia 1949 roku w Kupieninie na terenie parafii Mędrzechów w diecezji tarnowskiej. W 1967 roku wstąpił do Wyższego Seminarium Duchownego w Tarnowie, gdzie 27 maja 1973 roku przyjął święcenia kapłańskie z rąk bpa Jerzego Ablewicza. Po święceniach pracował jako wikariusz w parafii św. Elżbiety w Starym Sączu. W roku 1975 rozpoczął studia specjalistyczne z zakresu teologii dogmatycznej na Katolickim Uniwersytecie Lubelskim. Tam uzyskał licencjat $z$ teologii na podstawie pracy Pneumatologiczny wymiar Konstytucji dogmatycznej «Lumen gentium» (promotor abp Alfons Nossol). Następnie kontynuował studia w Innsbrucku w Austrii, gdzie w roku 1982 uzyskał doktorat z teologii dogmatycznej na podstawie rozprawy: Wpływ Soborowych Ojców Wschodu i Obserwatorów prawosławnych na teologię «Lumen gentium» (promotor ks. prof. Raymund Schwager SJ).

1 lutego 1983 roku rozpoczął pracę w watykańskiej Kongregacji Nauki Wiary i tam pracował 19 lat aż do chwili objęcia stolicy biskupiej w Radomiu. Był też postulatorem w Kongregacji do Spraw Kanonizacyjnych przy procesach Karoliny Kózkówny i ks. Romana Sitki z diecezji tarnowskiej, jak też Marii Julitty Ritz z diecezji Würtzburg w Niemczech. Podejmował prace nad przygotowaniem Katechizmu Kościoła katolickiego, zwłaszcza jego polskiego wydania, oraz współpracował z Radiem Watykańskim. 28 marca 2002 roku został mianowany przez Jana Pawła II biskupem radomskim. Głównym konsekratorem był kard. Joseph Ratzinger, współkonsekratorami: abp Józef Kowalczyk 
i bp Edward Materski. W strukturach Episkopatu Polski był przewodniczącym Komisji Nauki Wiary, członkiem Komisji Ekumenicznej i Polskiego Towarzystwa Mariologicznego oraz delegatem Konferencji Episkopatu Polski ds. Duszpasterstwa Emigracji. 30 czerwca 2008 roku otrzymał doktorat honoris causa Chrześcijańskiej Akademii Teologicznej w Warszawie. 9 listopada 2008 roku odznaczony został przez prezydenta Lecha Kaczyńskiego Krzyżem Kawalerskim Orderu Odrodzenia Polski za zaangażowanie na rzecz ratowania żydowskich zabytków cmentarnych.

W ciągu 7 lat pobytu w Radomiu dał się poznać jako wspaniały duszpasterz zaangażowany m.in. w działalność charytatywną. To właśnie z inicjatywy bpa Zimowskiego został wybudowany diecezjalny Ośrodek Edukacyjno-Charytatywny Emaus w Turnie koło Białobrzegów. Biskup Zimowski był także fundatorem i założycielem Fundacji Dać Sercom Nadzieję, doprowadził do końca rozbudowę Domu Matki i Dziecka Ofiar Przemocy w Rodzinie im. Jana Pawła II w Jasieńcu Iłżeckim. W Radomiu z inicjatywy biskupa Zygmunta Zimowskiego powstało też Centrum Myśli Benedykta XVI posiadające charakter naukowo-badawczy.

18 kwietnia 2009 papież Benedykt XVI mianował bpa Zygmunta Zimowskiego przewodniczącym Papieskiej Rady ds. Duszpasterstwa Służby Zdrowia, wynosząc go równocześnie do godności arcybiskupiej. Celem tej dykasterii jest pobudzanie i krzewienie pracy formacyjnej, studiów i działań w dziedzinie służby zdrowia, zarówno różnych międzynarodowych organizacji katolickich, jak i innych grup i stowarzyszeń. Rada upowszechnia, wyjaśnia i broni nauczania Kościoła, utrzymuje relacje z Komisjami Episkopatów podejmującymi problematykę zdrowotną, studiuje programy polityki zdrowotnej poszczególnych krajów i organizacji międzynarodowych, korzysta z pomocy ekspertów.

Ksiądz Arcybiskup jest autorem 120 publikacji, 35 listów pasterskich i redaktorem kilku pozycji książkowych, m.in. Pod opieka Matki i Królowej, Modlitwa - droga nawrócenia $i$ stużby, W trosce o petnię wiary, Carolina Kózka - il coraggio dell'innocenza.

Opublikował też kilkadziesiąt artykułów, współpracując z redakcją „L’Osservatore Romano”, ,Niedzieli” i „Rycerza Niepokalanej dla Polonii”. Angażował się w przygotowanie Katechizmu Kościoła katolickiego, szczególnie w wydanie w języku polskim. Współpracował także z Radiem Watykańskim, gdzie wygłaszał homilie, prelekcje, rekolekcje i komentarze do dokumentów watykańskich.

\section{Magistrale myśli}

W okresie posługi w diecezji radomskiej abp Zimowski prowadził przez 4 lata wykłady na Katolickim Uniwersytecie Lubelskim Jana Pawła II. Były to głównie wykłady z eklezjologii dla doktorantów Instytutu Teologii Dogmatycznej. Centralną ideę jego refleksji eklezjologicznej stanowiła idea communio. Widać tu pierwotną pasję Księdza Arcybiskupa, który zarówno w swojej pracy licencjackiej, jak i doktoracie badał teologię Lumen Gentium. Zarówno pneumatologia, jak i eklezjologia komunii wiele zawdzięczają wpływom myśli Wschodu chrześcijańskiego, a nade wszystko są one owocem powrotu teologów do Pisma Świętego i myśli ojców Kościoła jako podstawowych źródeł. Abp Zimowski preferuje obraz Kościoła jako komunii nie tyle dlatego, że jest to centralna 
idea w dokumentach Soboru Watykańskiego II, ile z tego powodu, że najlepiej oddaje i transponuje obraz Trójcy immanentnej na społeczność Kościoła oraz dobrze wyjaśnia zawarty w tym modelu postulat jedności i różnorodności. Tak jak życie Trójcy Świętej wypełnia jedność w różnorodności, tak i Kościół (którego bytu społecznego nie da się opisać w kategoriach socjologicznych) jest wspólnotą, w której spoiwem jest nie tyle „wola społeczna” lub prawo, ile działanie samej Trójcy. Owa jedność w różnorodności we wspólnocie Trójcy Przenajświętszej i we wspólnocie (komunii) Kościoła jest następstwem dwóch faktorów: te dwie społeczności są tworzone przez osoby i wzajemną miłość płynąca najpierw od Ojca przez Syna i Ducha Świętego do wspólnoty zbawienia. Miłość ze swej natury domaga się różnicy osób, by budować jedność, a jedność staje się życiodajna, gdy wypływa z komunii miłości. Abp Zimowski w ten sposób pokazuje, że idea kolegialności biskupów wynika też z eklezjologii komunii, gdyż każdy biskup jest nim wówczas, gdy jest w jedności z papieżem i kolegium biskupów całego świata, a ci z kolei spełniają świadomie zadanie udzielone im przez Chrystusa. W takim obrazie Kościoła nie ma miejsca na stagnację, gdyż jeśli Kościół jest communio, to jest także missio. Bóg chce dawać siebie i swoje zbawienie przez swój Kościół, ale domaga się całkowitego poddania swemu Duchowi. Ewangelizacja jest Jego dziełem oraz „dusz” - wedle terminologii św. Faustyny - poddanych Duchowi Świętemu.

W listach pasterskich abpa Zimowskiego do diecezjan radomskich również dominuje ta świeżość widzenia Kościoła jako wspólnoty zbawienia, którą nie tylko Chrystus ustanowił, ale nieustannie t w o r zy mocą Ducha Świętego przez sakramenty - zwłaszcza Eucharystię - słowo Boże i miłość-caritas. W tej wizji Kościoła uprzywilejowane miejsce ma Maryja, Matka Kościoła, która złączona przez Ducha Świętego z sercem swego Syna i upodobniona w swej miłości do Ojca, nieustannie uczestniczy całym sercem w rodzeniu ludzi dla Boga. Ona też najboleśniej odczuwa sprzeciw wobec Chrystusa. Na 42 listy pasterskie do diecezjan i 7 listów do Polonii, aż 14 listów zostało poświęconych Matce Bożej, 7 - tajemnicy Miłosierdzia Bożego, najwięcej tajemnicy Chrystusa obecnego w Eucharystii i w Kościele - 15, a pozostałe to listy dotyczące nowej ewangelizacji, wychowania chrześcijańskiego, praktykowania miłości chrześcijańskiej oraz sprawom społecznym, a zwłaszcza osobom chorym.

Aktualnie abp Zygmunt Zimowski jest przewodniczącym Papieskiej Rady ds. Duszpasterstwa Służby Zdrowia. Zaraz po otrzymaniu nominacji podkreślił, że „zadaniem Papieskiej Rady ds. Duszpasterstwa Służby Zdrowia będzie przede wszystkim formowanie sumień, tak by ludzie dostrzegali godność każdego życia - od poczęcia do naturalnej śmierci. - Moim zadaniem będzie wcielanie w życie papieskich dokumentów, promocja prawdziwej kultury życia i zdrowia, bowiem wciąż istnieje konieczność przybliżania tych dokumentów, szczególnie Służbie Zdrowia. Życie człowieka pochodzi od Boga, jest darem. Jakże dzisiaj dumnemu człowiekowi wydaje się, że jest panem życia. Dlatego tym bardziej trzeba promować kulturę zdrowia i rozwijać chrześcijańską antropologię" - podkreślił abp Zimowski. Rada pomaga więc uzdrowić służbę zdrowia poprzez promocję właściwej perspektywy człowieka i zdrowia. Chrystus uzdrawiał całego człowieka: jego ciało i ducha. Ewangeliści na pierwszym miejscu wśród cudów Jezusa wymieniają cuda uzdrowienia i uwolnienia z władzy złych duchów. Dziś Kościół jest sprzymierzeńcem człowieka, przypominając prawdę, że człowiek jest osobą i że 
cierpienia duchowe - w tym moralne - z powodu krzywdy, niesprawiedliwości i poniżenia, a nawet „zapędzenia w grzech" przez fałszywe ideologie wolności - że to wszystko nie może ujść naszej uwagi w służbie człowiekowi. Założyciel Fundacji św. Rafała (Ligi Verzé) kiedyś powiedział, że medycyna dziś powszechnie zdaje się zapominać, że przedmiotem jej troski jest integralnie osoba ludzka, a nie tylko ciało. To wartości duchowe ożywiają całego człowieka, a wśród nich wiara, nadzieja i miłość stanowią tkankę ludzkiej duchowej mocy.

Życzę więc Księdzu Arcybiskupowi, by Duch Święty udzielał Mu światła w promocji chrześcijańskiej wizji człowieka odkupionego przez Chrystusa i by w ten sposób Służba Zdrowia włączyła się w służbę samemu Bogu, Panu i Dawcy Życia. 
